\title{
Medication errors at intensive care units: nurses" knowledge and attitudes
}

\author{
Pavlína Štrbová, Eleonora Dostálová, Karel Urbánek \\ Department of Pharmacology, Faculty of Medicine and Dentistry, Palacký University in Olomouc, Czech Republic
}

Medication errors are among the most frequent causes of adverse events in hospitals. They occur more frequently at intensive care units (ICUs) than other types of hospital departments.

Aim: The main objective of this study was to determine the level of nurses' knowledge about correct use of medications at ICUs.

Methods: A questionnaire regarding high-risk medications was used to evaluate nurses' knowledge, and the experienced administration errors were reported by nurses working at ICUs for adult patients.

Results: A total of 240 respondents participated in the research. As far as their knowledge, in $23 \%$ was found sufficient and in $63 \%$ relatively sufficient. University-educated nurses achieved an average grade of 1.86 while secondary-educated nurses achieved an average mark of $2.02(p<0.05)$. Less than $23 \%$ of respondents experienced medication error at their workplace and $5 \%$ of the respondents admitted committing such error themselves.

Conclusions: While the knowledge of ICU nurses about medications is good, the reluctance to report medication errors remains apparent.

Key words: medication errors, nurses, questionnaire, pharmacology, knowledge.

Lékové chyby na jednotkách intenzivní péče: znalosti a postoje všeobecných sester

Lékové chyby patří mezi nejčastějši príčiny nežádoucích událostí v nemocnicích. Na jednotkách intenzivní péče se vyskytují častěji než na jiných typech oddělení.

Cíle: Hlavním cílem této práce bylo zjistit úroveň znalostí sester o správném používání léčiv na jednotkách intenzivní péče.

Metodika: Ke zjištění znalostí všeobecných sester pracujících na JIP pro dospělé pacienty byl použit dotazník zaměřený na vysoce rizikové léky a dále byly zjištovány jejich osobní zkušenosti s lékovými chybami.

Výsledky: Výzkumu se zúčastnilo 240 respondentů. Pokud jde o znalosti, u $23 \%$ z nich byly hodnoceny jako dostatečné a u $63 \%$ jako relativně dostatečné. Vysokoškolsky vzdělané sestry dosáhly průměrné hodnocení 1,86, zatímco středoškolsky vzdělané 2,02 $(p<0,05)$. Méně než $23 \%$ respondentů uvedlo zkušenost s lékovou chybou na svém pracovišti a $5 \%$ přiznalo vlastní lékovou chybu. Závěr: Zatímco znalosti všeobecných sester o používaných lécích jsou dobré, zjevná zůstává neochota k oznamování lékových chyb.

Klíčová slova: lékové chyby, všeobecné sestry, dotazník, farmakologie, znalosti.

\section{Introduction}

Medication errors and adverse drug reactions are among the most frequent causes of adverse events in hospitals. These errors may lead to disability and death in up to $6.5 \%$ of hospital admissions (1). Medication errors occur more frequently at intensive care units (ICUs) than other types of hospital departments. Patients stay there for a longer time and most medications are given to them parenterally (2). Critically ill patients often require life saving treatments and are often exposed to medications with narrow therapeutic index. Therefore, caring for them requires special attention (3).
In the Sentinel Events Evaluation study (SEE), a snapshot of errors recorded on more than 200 ICUs, 10.5 medication errors were identified per 100 patient days, split about equally between prescription errors and administration errors (4). In the Critical Care Safety Study, medication errors counted for almost $78 \%$ of all serious 
ORIGINÁLNÍ PRÁCE I

Tab. 1. Didactic test

\begin{tabular}{|c|c|c|c|c|}
\hline $\begin{array}{l}\text { Question } \\
\text { number }\end{array}$ & Question & Righ & nswer & Value difficulty (Q) \\
\hline 1. & It is possible to arbitrarily replace an insulin syringe with a standard 2-ml syringe when administering insulin & & NO & 9.17 \\
\hline 2. & Before opening, insulin must be stored in its storage bottle in a refrigerator (at a temperature of $2-8^{\circ} \mathrm{C}$ ) & YES & & 4.58 \\
\hline 3. & $7.5 \% \mathrm{KCl}$ can be stored in the pharmacy alongside other commonly available medications & & NO & 7.50 \\
\hline 4. & $\begin{array}{l}1 \mathrm{ml} \text { of undiluted adrenaline can be administered intravenously for common allergic reaction (itching, } \\
\text { redness, urticaria) }\end{array}$ & & NO & 7.50 \\
\hline 5. & $\begin{array}{l}\text { Calcium gluconicum } 10 \% \text { can be used to replace Calcium chloratum Biotika } 10 \% \text { in the case of shortage of } \\
\text { the latter }\end{array}$ & & NO & 22.08 \\
\hline 6. & When you dilute Thiopental $0.5 \mathrm{~g}$ into a $20-\mathrm{mL}$ syringe, $5 \mathrm{ml}$ will contain $0.1 \mathrm{~g}$ & & NO & 8.75 \\
\hline 7. & Nurses can administer opioid analgesics into an epidural catheter & & NO & 80.83 \\
\hline 8. & $\begin{array}{l}\text { It is possible to dilute an antibiotic (e.g. gentamicin) in a balanced crystalloid solution for intravenous } \\
\text { administration, e.g. Plasmalyte }\end{array}$ & & NO & 12.08 \\
\hline 9. & $\begin{array}{l}\text { Administration of crushed slow-release theophylline tablets into a nasogastric tube is considered the correct } \\
\text { procedure }\end{array}$ & & NO & 12.50 \\
\hline 10. & $\begin{array}{l}\text { Unasyn } 1.5 \mathrm{~g} \text { (containing ampicillin and sulbactam) can be administered intravenously to a patient with an } \\
\text { allergy to penicillin antibiotics }\end{array}$ & & NO & 12.08 \\
\hline 11. & Intramuscular injection of FRAXIPARINE is contraindicated & YES & & 11.67 \\
\hline 12. & Dyskinesia (e.g. Parkinson syndrome) can occur after intravenous administration of Degan & YES & & 25.83 \\
\hline 13. & In the preparation of an infusion, furosemide may be mixed with pH-lowering agents, e.g. vitamin B & & NO & 7.92 \\
\hline 14. & VUAB Hydrocortisone $100 \mathrm{mg}$ is diluted for intravenous infusion using $4 \mathrm{~mL}$ of sterile water for injection & & NO & 37.50 \\
\hline 15. & Another drug can be added into an infusion containing Helicid 40 mg for infusion & & NO & 9.17 \\
\hline 16. & $20 \%$ glucose solution can cause venous irritation following peripheral administration & YES & & 5.00 \\
\hline
\end{tabular}

mistakes. Nearly two-thirds of serious medical errors in ICUs occurred during the ordering or execution of treatments, especially medications (5). The consequences of medication error in critical care are often serious: according to Osmond et al., $9.8 \%$ of medication errors require life-sustaining treatment (6).

Nurses play a key role in the prevention of the medication errors. Therefore, it is important to provide them sufficient information about the issue and adequate training in its prevention and reporting. They should be motivated to report medication errors without fear of any negative consequences $(7,8)$.

Currently, there are nurses with three different levels of education in the Czech Republic. The first level of education includes secondary nursing school. Nurses were educated at secondary nursing schools from 1950 s until 2004. Since then, only higher nursing schools or universities graduate general nurses. The second level of education is represented studying at higher nursing schools. Graduates of this type of education are awarded a certified specialist and entitled to use the designation nurse and allowed to work without supervision. The third level of education is the university degree in nursing. University graduates are receiving a Bachelor's or Master degree and are allowed to work without supervision.
Besides these educational levels, specialization courses for general nurses are also available at the National Centre of Nursing and Non-medical Health Professions. For the nurses' work at an ICU, it is recommended (but not absolutely necessary) to undergo specialization course in intensive care nursing.

Hitherto, many studies using the method of questionnaire survey to ascertain the knowledge of nurses about proper handling of medicines were published. Their methodology is of varying quality and often is focused on single type of medications or nurses of specific medical specialization. Also, these studies rarely compare the knowledge of nurses with different level of education. We believe that of high-quality methodology is the study by Lan et al., performed at the cohort of pediatric nurses (9). Therefore, we have considered useful to adapt methodology of this study for the survey focused on nurses working at ICUs for adult patients.

The main objective of this study was to determine the level of nurses' knowledge about correct use of medications at ICUs. The other objectives were to compare the differences of nurses' knowledge according to their education level and experience in the field, to determine the factors contributing to errors occurrence during the use of medications at IUCs and find out the prevalence of these errors at IUCS at selected hospitals in the Czech Republic.

\section{Methods}

\section{Sample of respondents}

The research was conducted in selected hospitals in Olomouc, Zlín, South Moravia, Moravia-Silesia and Prague Regions. The research sample consisted of nurses working at hospital IUCs. Their highest education level was secondary nursing school, higher nursing school or university. Some respondents also have completed specialization course in intensive care nursing.

\section{Questionnaire}

\section{Development and validation}

A combination of quantitative and qualitative research was used for this study. Both types of research were performed by a questionnaire. The modified questionnaire published by Lan et al. (9) was used after adjustment to the field of intensive care nursing. This questionnaire was pilot tested and several items were adjusted based on the results of this preliminary research. Content and construct validity were applied to examine whether the 30 questions were appropriate and sensitive enough to differentiate knowledge levels. 


\section{| ORIGINÁLNÍ PRÁCE}

In order to examine the importance, relevance and appropriateness of the questionnaire and to understand the reactions when answering questions, face validity was applied. Then the questionnaire was distributed in printed or electronic form through the staff and head nurses.

\section{Part 1}

The first part of the questionnaire, which included 7 items, was focused on demographic and factual data about the respondents. This part of the questionnaire examined the age, sex, length of experience, the highest education level, finished school / university, completed specialization course in intensive care nursing, current position at the ICU (registered nurse, staff nurse or head nurse) and the type of the ICU.

\section{Part 2}

The second part of questionnaire consisted of the didactic test including 16 questions, focused to information about the level of nurses' knowledge on high-alert medications frequently used in critical care. List of High-Alert Medications that created ISMP was used for constructing questions (10). Results were evaluated using a standardized four-point grading scale. For each question, the value of difficulty $(Q)$ was calculated. This value indicates the percentage of respondents who answered the question incorrectly or missed it. The question of high difficulty is defined by the $\mathrm{Q}$ greater than eighty. On the contrary, questions are considered easy when the $\mathrm{Q}$ value is lower than twenty. Didactic test is shown in Table 1.

\section{Part 3}

The third part of questionnaire, consisting of 7 items, focused on nurses' experience with the medication errors and self-assessment of their knowledge in this field. University graduated respondents were asked whether pharmacology courses, which they completed during nursing undergraduate curriculum, have provided a benefit for their practice.

\section{Ethical considerations}

The study design provided autonomy, giving nurses the freedom to decide whether to participate and provide information. A cover letter attached to each questionnaire explained that participation was voluntary and returned questionnaire signified consent. Participants were asked not to place individual identifiers on the questionnaire to secure confidentiality. This research was approved by the deputy or managers of nursing care of each participating hospital.

\section{Data processing}

Data obtained from the questionnaires was processed in Excel tables and then imported into SPSS statistical software version 20. 0. The differences in the occurrence of observed phenomena in nominal variables were tested using the chi-square test. The difference in test results between different education levels was tested using the independent sample t-test with Levene's test for equality of variances. Pivot tables were used for testing of qualitative data. The strength of the dependence of those variables was also tested using the chi-square test.

\section{Results}

A total of 240 respondents participated in the research. Nearly half of respondents (49.17\%) were older than 36 years of age. Respondents were predominantly female (92.92\%). All respondents general nurses at ICUs. Respondents with the working experience of 11 or more years were the most represented (45.00 \%) in the sample. According to the level of education, the secondary nursing school graduates were most prevalent ( $40.83 \%)$. A total of $55 \%$ of respondents passed the specialization course in intensive care nursing at the National Centre of Nursing and Non-medical Health Professions. More detailed demographic and factual data are shown in Table 2.

The second part of the questionnaire consisted of didactic test with 16 questions. Four-point grading scale was used to evaluate the test. Each level of this classification had set-point margin. Respondent was awarded 1 point for each correct answer always. A total of $23 \%$ of respondents received the best classification level (grade 1). The largest group of respondents passed the test with the classification grade 2 (almost $63 \%$ ). Less than $14 \%$ of respondents obtained a classification grade 3 . Only one respondent failed. Results of the didactic test are shown in Figure 1.

We also focused on diversity of results by highest educational attainment in assessing the didactic test. It was found that the results of graduates of secondary or higher nursing schools differs from that of university educated nurses. University-educated nurses achieved an
Tab. 2. Background and characteristics of nurses

\begin{tabular}{|l|l|l|}
\hline Characteristics & $\mathbf{n}$ & $\%$ \\
\hline Age (years) & & \\
\hline$\leq 25$ & 26 & 10.83 \\
\hline $26-30$ & 62 & 25.83 \\
\hline $31-35$ & 34 & 14.17 \\
\hline$\geq 36$ & 118 & 49.17 \\
\hline Sex & & \\
\hline Female & 223 & 7.08 \\
\hline Male & 17 & 92.92 \\
\hline $\begin{array}{l}\text { Intensive care nursing } \\
\text { practice (years) }\end{array}$ & & \\
\hline$\leq 2$ & 32 & 13.33 \\
\hline 3-5 & 49 & 20.42 \\
\hline 6-10 & 51 & 21.25 \\
\hline$\geq 11$ & 108 & 45.00 \\
\hline Education & & \\
\hline Secondary & 98 & 40.83 \\
\hline Higher & 56 & 23.33 \\
\hline University & 86 & 35.83 \\
\hline $\begin{array}{l}\text { Specialized education } \\
\text { (PSS ARIP) }\end{array}$ & & \\
\hline Yes & 133 & 55.42 \\
\hline No & 107 & 44.58 \\
\hline Position & & \\
\hline Registered nurse & 224 & 93.33 \\
\hline Staff nurse & 13 & 5.42 \\
\hline Head nurse & 3 & 1.25 \\
\hline Department & 102 & 42.50 \\
\hline $\begin{array}{l}\text { Anesthesiology and } \\
\text { Resuscitation Department }\end{array}$ & 74 & 30.83 \\
\hline Internal medicine IUCs* & 64 & 26.67 \\
\hline Surgical IUCs** & & \\
\hline & & \\
\hline (1) & & \\
\hline
\end{tabular}

*Internal IUCs included: Hematology IUCS, Internal IUCS, Cardiology IUCS, Metabolic IUCS, Neurological IUCS, Department of Intensive Medicine

**Surgical IUCs included: Surgical IUCS, Cardiac IUCs, Neurosurgical IUCS, Obstetric-Gynecological IUCS, TraumaIUCS

average grade of 1.86 while secondary-educated nurses achieved an average mark of 2.02 ( $p<$ 0.05). More detailed results from a comparison of respondent groups among them are shown in Table 3. On the contrary, undergoing of the specialization course in intensive care nursing didn't affect the results of this test (1.93 and 1.90 for those with and without the specialization course, respectively, non-significant).

The third part of the questionnaire was focused on medication errors and nurses attitude to the benefits and needs of education in pharmacology. Respondents were asked whether any medication error occurred at their ICU and whether they made such an error themselves during the last 3 months at their workplace. Less than $23 \%$ of respondents experienced medication error at their workplace and $5 \%$ of the respondents committed the error themselves. We also investigated the relationship 
Fig. 1. Knowledge level based on results of the didactic test $0.42 \%$

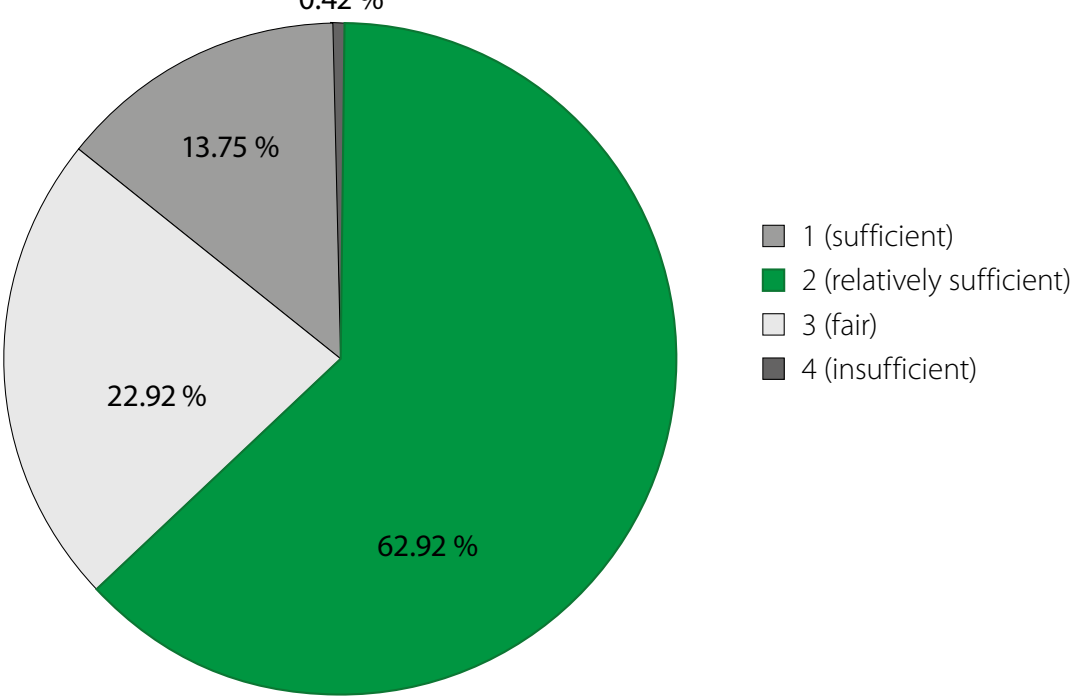

Tab. 3. Results of the didactic test by educational attainment

\begin{tabular}{|c|c|c|c|c|c|c|c|}
\hline \multirow{11}{*}{ 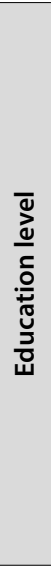 } & & & \multicolumn{4}{|c|}{ Grade of didactic test } & \multirow{2}{*}{ Total } \\
\hline & & & 1 & 2 & 3 & 4 & \\
\hline & \multirow{3}{*}{$\begin{array}{l}\text { secondary } \\
\text { education }\end{array}$} & Number & 26 & 59 & 12 & 1 & 98 \\
\hline & & $\begin{array}{l}\% \text { of } \\
\text { category }\end{array}$ & 26.53 & 60.20 & 12.24 & 1.02 & 100.00 \\
\hline & & $\%$ of total & 10.83 & 24.58 & 5.00 & 0.42 & 40.83 \\
\hline & \multirow{3}{*}{$\begin{array}{l}\text { higher } \\
\text { education }\end{array}$} & Number & 15 & 35 & 6 & 0 & 56 \\
\hline & & $\begin{array}{l}\% \text { of } \\
\text { category }\end{array}$ & 26.80 & 62.50 & 10.70 & 0.00 & 100.00 \\
\hline & & $\%$ of total & 6.20 & 14.60 & 2.50 & 0.00 & 23.33 \\
\hline & \multirow{3}{*}{$\begin{array}{l}\text { university } \\
\text { education }\end{array}$} & Number & 14 & 57 & 15 & 0 & 86 \\
\hline & & $\begin{array}{l}\% \text { of } \\
\text { category }\end{array}$ & 16.28 & 66.28 & 17.44 & 0.00 & 100.00 \\
\hline & & $\%$ of total & 5.83 & 23.75 & 6.25 & 0.00 & 35.83 \\
\hline & \multirow{2}{*}{ Total } & Number & 55 & 151 & 33 & 1 & 240 \\
\hline & & $\%$ of total & 22.92 & 62.92 & 13.75 & 0.42 & 100.00 \\
\hline
\end{tabular}

between the length of working experience and making medication errors. It was found that the length of work experience didn't play a role in the self-reported incidence of making medication errors (4.3\% vs $6.5 \%$ incidence for those with less than 10 years of experience and those with 10 or more, non-significant). Furthermore, respondents had to choose three factors most contributing to the medication errors from the 9 proposed answers. The factors were most represented: inattention (27\%), increased workload (20\%) and inexperienced / new staff (16\%). Finally, university graduated respondents were asked whether pharmacology courses, which they completed during nursing undergraduate curriculum, have provided a benefit for their practice. Absolute majority (99.00\%) of responses were positive.

\section{Discussion}

The study "Medication errors in pediatric nursing: Assessment of nurses' knowledge and analysis of the Consequences of errors" was the model on the methodology of this research (9). However, the model study examined the knowledge and the incidence of medication errors in pediatric intensive care. Our study examined the same issue in adult

A total of 240 respondents participated in the research. Respondents were predominantly female (92.92\%). The age range was from 25 years to 36 years or more. Nearly half of respondents (49.17\%) were older than 36 years of age. The study also focused on the respondents' education level in nursing. Most respondents had secondary education. Nearly a quarter (23.33\%) had higher education and $36 \%$ had a university degree, compared with $39 \%$ in the study by Lan et al. (9). Nurses in the Czech Republic could also have a specialization course in intensive care nursing. There were $55 \%$ nurses in our study which have had finished the course. Also some pediatric nurses (40.50 \%) in patients. the abovementioned model study had similar specialization course (2014).

Most respondents had 11 years and more of experience (45.00\%). The least proportion of respondents had experience up to 2 years (13.33\%). Surprisingly, a previous study from Japan has revealed reverse dependence of error making on the length of practice (11). Experienced nurses made more errors than less-experienced nurses in that study. Authors of the study stated that there is the possibility that some medication errors occur due to preoccupation that nurses feel it is less necessary to explain and confirm everything related to medication administrations as their length of service increase. On the contrary, in our study nurses with longer experience didn't make the errors more often than less experienced nurses.

The didactic test was focused on the respondents' knowledge of the high-alert medications used frequently in the intensive care. The List of High-Alert Medications, guidelines issued by World Health Organization (Control of Concentrated electrolyte solutions) and the Summaries of Product Characteristics were used for formulating questions regarding high-alert medication used in critical care. Questions on antibiotics, vasopressors, glucocorticoids sedatives, anticoagulants, anti-ulcer drugs and solutions used for the fluid resuscitation were asked in the test. Most of these drugs are parenterally administered (12).

Results of the test were evaluated using a standardized four-point grading scale: grade 1 (sufficient) reached $22.92 \%$ of respondents, $62.92 \%$ reached grade 2 (relatively sufficient), $13.75 \%$ grade 3 (fair) and $0.42 \%$ grade 4 (insufficient). Pediatric nurses in a study of Lan et al. also achieved similar results (2014). The most difficult question in our questionnaire appeared to be if nurses can apply opioid analgesics into the epidural catheter. In this issue, the rate of incorrect answers was $80.83 \%$. A possible explanation is that some hospitals have created standards that intensify the competence of personnel, although the national regulations generally reserve this type of administration to medical doctors. Another two items with highest occurrence of errors were focused on the numerical abilities of respondents. In these issues, errors occurred in $8.75 \%$ and $37.50 \%$, respectively. This type of mistake might have serious consequences during administration of parenteral drugs requiring dilution prior to administration with variable dosage according to the weight of the patient (13). 


\section{| ORIGINÁLNÍ PRÁCE}

Tab. 4. Results of Part 3 of the questionnaire: nurses' experience with medication errors and self-assessment of their knowledge

\begin{tabular}{|c|c|c|}
\hline Items & $\mathrm{n}$ & $\%$ \\
\hline \multicolumn{3}{|c|}{ Self-estimated knowledge of pharmacology } \\
\hline Inadequate & 19 & 7.92 \\
\hline Satisfying & 212 & 88.33 \\
\hline Great & 9 & 3.75 \\
\hline \multicolumn{3}{|c|}{ Experience of medication error in the workplace } \\
\hline Yes & 69 & 28.75 \\
\hline No & 171 & 71.25 \\
\hline \multicolumn{3}{|c|}{ Factors contributing to medication errors } \\
\hline Inattention & 172 & 26.88 \\
\hline Increased workload & 130 & 20.31 \\
\hline Inexperienced (new) staff & 103 & 16.09 \\
\hline Lack of knowledge & 90 & 14.06 \\
\hline Understanding physicians' prescription & 64 & 10.00 \\
\hline Other* & 80 & 12.5 \\
\hline \multicolumn{3}{|l|}{ Experience of one's own error } \\
\hline Yes & 13 & 5.42 \\
\hline No & 227 & 94.58 \\
\hline \multicolumn{3}{|c|}{ Benefit of a university course of pharmacology for intensive care practise } \\
\hline Yes & 58 & 67.44 \\
\hline No & 28 & 32.56 \\
\hline \multicolumn{3}{|c|}{ Need for further education in the field of pharmacotherapy in intensive care } \\
\hline Positive & 231 & 95.25 \\
\hline Negative & 9 & 3.75 \\
\hline
\end{tabular}

Differences of results of the didactic test between graduates of different levels of nursing education were also tested. As expected, it was found that the results of secondary or higher nursing schools graduates were significantly worse than that of university educated nurses. On the contrary, finishing the specialization course in intensive care nursing didn't affect the results of this test. Recent study by Bülbül et al. (14), focused on knowledge related with drug administration and drug administration errors, unexpectedly showed that undergraduate nurses were more successful in calculating doses. This may indicate that level of education might be less important factor than individual attitude or abilities of nurses.

In questions focused on medication errors, respondents were asked whether any such error occurred at their ICU and whether they made such an error themselves during the last 3 months at their workplace. Less than $23 \%$ of respondents experienced medication error at their workplace and $5 \%$ of the respondents made the error themselves. When we com-

\section{LITERATURE}

1. Lisby M, Nielsen LP, Mainz J. Errors in the medication process: frequency, type, and potential clinical consequences. pare the results with those from the study by Kim et al. (15), in which the misconduct admitted $63.6 \%$ of respondents, our result is substantially lower. Unfortunately, it is not possible to ensure that respondents truly accountable to the items in the survey. Nurses are often afraid to report their own mistakes, because of potential consequences (16). Fear of punishment, reputational risk medical devices or nescience in the field of medication errors are the cause of the low number of reported errors in most cases. The solution might be the direct observation, which is the most objective method for error detection. However, this method of data collection was found difficult and costly $(17,18)$.

Furthermore, the respondents had to choose three factors most contributing to the medication errors from the 9 proposed possibilities. The most frequently reported causes were: inattention (26.88\%), increased workload (20.31 \%) and inexperienced or new staff (16.09\%). In the study by Tang et al. the same issues were found in the same order - inattention was reported in $86.10 \%$, increased workload $37.50 \%$ and new staff in $37.50 \%$ (19).

The major limiting factor of this research was just its focus on the nurses' errors. Establishing cooperation with nurses was not easy; they generally did not feel comfortable with testing on their knowledge. They also did not admit that they could make a mistake that could harm the patient or believed that the reporting of such errors could result in a disciplinary action.

We believe that prevention of medication errors must be implemented in every part of the process of drug use. Registering and publishing cases of medication errors is not enough. It is necessary to discover the cause and determine the severity of these errors $(20,21)$. Primarily, it is necessary to uncover any risk behavior of the medical staff. Education of nurses in the pharmacology and/or clinical pharmacology is also an important intervention to prevent medication errors. This basic knowledge must be also strengthened by practical training (22). It is advisable to apply a multidisciplinary approach and involve pharmacists in preventing medication errors. Involvement of clinical pharmacists at hospital wards can reduce substantially the incidence of medication errors (23). Good undergraduate and continuous postgraduate education of nurses plays the most important role in preventing of medication errors.

\section{Conclusion}

Results of the research were quite satisfactory. Nearly $86 \%$ of nurses achieved sufficient or relatively sufficient rating in the evaluation of their knowledge by the didactic test. The level of knowledge of university-educated nurses was significantly higher than that with secondary or higher education. On the other hand, the results of the didactic test were not different between respondents with or without a specialization in the field of intensive care nursing. The most effective way to avoid medication errors is prevention at all stages of the process of dealing with drugs, from their prescription to the monitoring of the patient's condition after their administration.

Supported by Grant IGA_LF_2019_011 
ORIGINÁLNÍ PRÁCE I

An observational study. Aust Crit Care 2008; 21(2): 110-116. 3. Manias E, Williams A, Liew D. Interventions to reduce medication errors in adult intensive care: a systematic review. $\mathrm{Br} J$ Clin Pharmacol 2012; 74(3): 411-423.

4. Valentin A, Capuzzo M, Guidet B, Moreno RP, Dolanski L, Bauer P, Metnitz PH. Patient safety in intensive care: results from the multinational Sentinel Events Evaluation (SEE) study. Intensive Care Med 2006; 32(10): 1591-1598

5. Rothschild JM, Landrigan CP, Cronin JW, Kaushal R, Lockley SW, Burdick E, Stone PH, Lilly CM, Katz JT, Czeisler CA, Bates DW. The Critical Care Safety Study: The incidence and nature of adverse events and serious medical errors in intensive care. Crit Care Med 2005; 33(8): 1694-1700.

6. Osmon S, Harris CB, Dunagan WC, Prentice D, Fraser VJ, Kollef $\mathrm{MH}$. Reporting of medical errors: an intensive care unit experience. Crit Care Med 2004; 32(3): 727-733.

7. Ofosu R, Jarrett P. Reducing nurse medicine administration errors. Nurs Times 2015; 111(20): 12-14.

8. Likic R, Maxwell SR. Prevention of medication errors: teaching and training. Br J Clin Pharmacol 2009; 67(6): 656-661. 9. Lan YH, Wang KW, Yu S, Chen IJ, Wu HF, Tang FI. Medication errors in pediatric nursing: Assessment of nurses' knowledge and analysis of the consequences of errors. Nurse Educ Today 2014; 34(5): 821-828.

10. Institute for Safe Medication Practices, 2014. ISMP's List of High-Alert Medications. Retrieved from https://www.ismp. org/tools/highalertmedications.pdf

11. Kazaoka T, Ohtsuka K, Ueno K, Mori M. Why nurses make medication errors: A simulation study. Nurse Educ Today 2007; 27(4): 312-317.

12. Valentin A, Capuzzo M, Guidet B, Moreno R, Metnitz B. Errors in administration of parenteral drugs in intensive care units: multinational prospective study. BMJ 2009: 12, 338: b814.

13. Brady AM, Malone AM, Fleming S. A literature review of the individual and systems factors that contribute to medication errors in nursing practice. J Nurs Manag 2009; 17(6): 679-697. 14. Bülbül A, Kunt A, Selalmaz M, Sözeri Ş, Uslu S, Nuhoğlu A Assessment of knowledge of pediatric nurses related with drug administration and preparation. Turk Pediatri Ars 2014; 49(4): 333-339.

15. Kim KS, Kwon SH, Kim JA, Cho S. Nurses'perceptions of medication errors and their contributing factors in South Korea. J Nurs Manag 2011; 19(3): 346-353.
16. Bifftu BB, Dachew BA, Tiruneh BT, Beshah DT. Medication administration error reporting and associated factors among nurses working at the University of Gondar referra hospital, Northwest Ethiopia, 2015. BMC Nurs 2016; 18: 15-43. 17. Wheeler SJ, Wheeler DW. Medication errors in anaesthesia and critical care. Anaesthesia 2005; 60(3): 257-273.

18. Dougherty L, Sque M, Crouch R. Decision-making processes used by nurses during intravenous drug preparation and administration. J Adv Nurs 2012; 68(6): 1302-1311.

19. Tang FI, Sheu SJ, Yu S, Wei IL, Chen CH. Nurses relate the cotributing factors involved in medication errors. J Clin Nurs 2007; 16(3): 447-457.

20. Malý J, Hojný M, Vlček J. Léková pochybení a zkušenost s jejich monitorováním I. Prakt lékáren 2009; 5(6): 290-293. 21. Ioannidis JP, Lau J. Evidence on interventions to reduce medical errors. J Gen Intern Med 2001; 16(5): 325-334. 22. Page K, McKinney AA. Addressing medication errors The role of undergraduate nurse education. Nurse Educ Today 2007; 27(3): 219-224

23. Bond CA, Raehl CL, Franke T. Clinical pharmacy services, hospital pharmacy staffing, and medication errors in United States hospitals. Pharmacotherapy 2002; 22(2): 134-147.

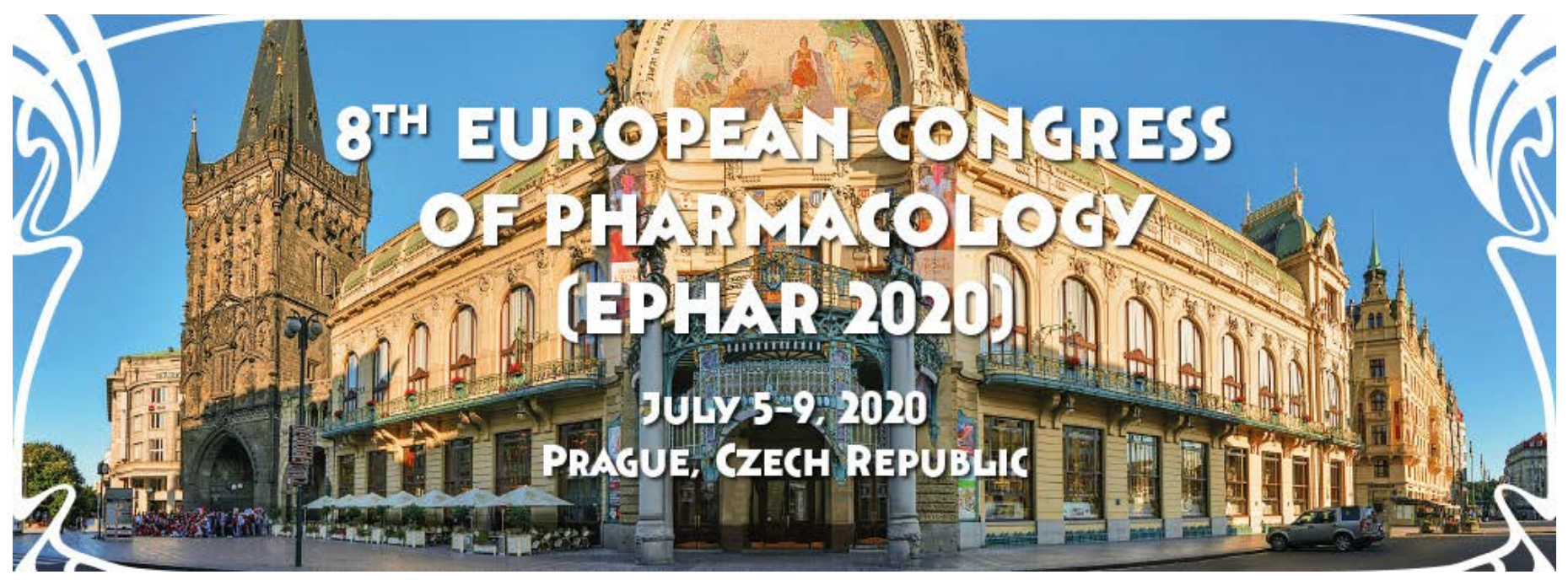

